\title{
Spatial Distribution of Adults and Nymphs of Euschistus heros (F.) (Hemiptera: Pentatomidae) on Bt and Non-Bt Soybean
}

\author{
Paulo Rogério Beltramin da Fonseca ${ }^{1}$, Marcos Gino Fernandes ${ }^{2}$, Wagner Justiniano ${ }^{2}$, Leonardo Hiroito Cavada ${ }^{1}$ \\ \& João Alfredo Neto da Silva ${ }^{1}$ \\ ${ }^{1}$ Faculdade de Ciências Agrárias, Programa de Pós-Graduação em Agronomia (Produção Vegetal), Universidade \\ Federal da Grande Dourados, Dourados/MS, Brazil \\ ${ }^{2}$ Faculdade de Ciências Biológicas e Ambientais, Programa de Pós-Graduação em Entomologia e Conservação \\ da Biodiversidade, UFGD, Universidade Federal da Grande Dourados, Dourados/MS, Brazil \\ Correspondence: Paulo Rogério Beltramin da Fonseca, Universidade Federal da Grande Dourados (UFGD), \\ Faculdade de Ciências Agrárias. Rodovia Dourados-Itahum, Km 12, Caixa Postal: 533, Bairro Aeroporto, CEP: \\ 79804-970, Dourados/MS, Brazil. E-mail: prbeltramin@hotmail.com
}

Received: January 21, 2014 Accepted: March 20, 2014 Online Published: May 15, 2014

doi:10.5539/jas.v6n6p131 URL: http://dx.doi.org/10.5539/jas.v6n6p131

\begin{abstract}
The knowledge of the arrangements of dispersion of insect pests in soybean cultivars is needed to improve the monitoring and control. The objective of this study was to evaluate the spatial distribution of adults and nymphs of Euschistus heros in Bt and non-Bt soybean into two regions, under field conditions. The experimental area located in Dourados and Douradina, Mato Grosso do Sul. For the evaluations we used the method of cloth-to- beat, where we collected one sample per plot randomly from each experimental area. Evaluations were performed at 7, 14, 21, $28,35,42,49,56,63,70,77,84,91,98$ days after emergence (DAE). For data analysis, the rates of dispersion (variance/average Morisita index and exponent k. Negative Binomial Distribution) and theoretical frequency distributions (Poisson, Binomial and Negative Binomial Positive) were estimated at 1-5 \% probability. Adults of $E$. heros are arranged differently for $\mathrm{Bt}$ and non-Bt soybean and between regions, since in both cultivars and locations, individuals of the populations evaluated in probabilistic set arrangements negative binomial distribution (aggregate), Poisson (random) and positive binomial distribution (uniform), as the days after soybean emergence. The nymphs of $E$. heros showed aggregated spatial arrangement, being distributed similarly for $\mathrm{Bt}$ and non-Bt soybean and regions, setting a negative binomial distribution model.
\end{abstract}

Keywords: Glycine max L, damage, sampling, horizontal dispersion, Bt crop

\section{Introduction}

Soybean [Glycine $\max$ (L.) Merrill] is the crop with the largest acreage in the world with high yield potential (Fonseca et al., 2013b; Yokomizo et al., 2013). The crop is attacked by different insect-pests from sowing till harvest, among which, Euschistus heros (Fabricius, 1794) (Hemiptera: Pentatomidae) being the most abundant and prevalent in agricultural areas in Brazil (Corrêa-Ferreira \& Panizzi, 1999; Panizzi et al., 2012; Krinski et al., 2013). Bedbugs occur in soybean at all stages and are harmful from the beginning of pod formation until grain maturity (Zambiazzi et al., 2012). They reach the seeds through the insertion of the mouthparts in vegetables, making them shriveled and wrinkled, affecting consequently the yield and quality of grain (Panizzi \& Slansky Junior, 1985).

The damage caused by E. heros when uncontrolled can get up to 30\% on soybean (Vivan \& Degrande, 2011). To reduce losses, control of this insect is accomplished through chemical insecticide applications, from the vegetative phase of the plant, and are not always effective (Corrêa-Ferreira, 2005; Sosa-Gómez \& Silva, 2010).

Considering the efficiency of the conventional system, it can be considered that, the Bt-plants is a tool that assists in the productive systems (Homrich et al., 2008). The main objective in the generation of Genetically Modified Organisms (GMO) is to increase the plant resistance to insects (Yuan \& Knauf, 1997; Yu et al., 2011; Dutra et al., 2012a), with this; despite the great advances in Bt technology poses to world agriculture, their adoption in some regions may be affected positively or negatively depending on the characteristics of each locality (Barros \& Degrande, 2012). 
Therefore, soybean yield is defined by the interaction between the plant and the environment and the management of the insect pests (Pereira et al., 2011), thus high yields are only obtained when such conditions are favorable, at all stages of growth culture.

The management of E. heros in soybean should include the adoption of control measures based on population levels of species monitored by periodic sampling. The first step in designing a sampling plan is the knowledge of the spatial distribution of the species of interest, to establish appropriate criteria on population (Barbosa, 2003). Thus, knowledge of a fast and efficient way of pest sampling, especially on large areas of cultivation, is essential that the Integrated Pest Management (IPM) is satisfactorily used (Fernandes et al., 2003).

Despite the benefits obtained from the Bt cultivar, it is not known exactly how transgenic plants affect the populations of organisms in an agroecosystem (Rodrigues et al., 2010). Understanding the behavior of distribution of non-target pests in transgenic plants makes it necessary to know the shape of the spatial arrangement of this insect in this new technology to determine whether or not to change some characteristics of the sample such as the sample size and sampling units.

There is demand for research with the goal of evaluating the spatial arrangement of E. heros in $\mathrm{Bt}$ and non-Bt soybean; moreover, there is still lack of scientific information about the behaviour of this pest in different localities. In this context, this study aimed to evaluate the spatial distribution of adults and nymphs of $E$. heros in Bt and non-Bt soybean in two regions under field conditions.

\section{Material and Methods}

The experiment was conducted under field conditions in two experimental areas located at Rincão Porã Farm, the geographic coordinates $22^{\circ} 14^{\prime} 25^{\prime \prime} \mathrm{S}, 54^{\circ} 42^{\prime} 60.7^{\prime \prime} \mathrm{W}$ and altitude of $403 \mathrm{~m}$ above mean sea level in the town of Dourados and Boa Sorte Farm in the geographical coordinates $22^{\circ} 01^{\prime} 07^{\prime \prime} \mathrm{S}, 54^{\circ} 32^{\prime} 15^{\prime \prime} \mathrm{W}$ and altitude of $310 \mathrm{~m}$ above mean sea level in the municipality of Douradina during harvest season, 2011/12. The soil of the area is classified as Typic Distroferric (RH) of loamy soil. The climate, according to Köppen's humid mesothermal, Cwa type, with annual average temperatures and precipitation ranging from $20^{\circ} \mathrm{C}$ to $24^{\circ} \mathrm{C}$ and $1.250 \mathrm{~mm}$ to $1.500 \mathrm{~mm}$, respectively (Fietz \& Fisch, 2006). For management of two experimental areas with soybean, we used the no-tillage system, and corn (Zea mays L.) as preceding crop. The area of this experiment was dried with glyphosate combined with mineral oil (2.0 1.ha ${ }^{-1}+0.51 . \mathrm{ha}^{-1}$, respectively).

The seeds used were Bt soybean AL 6910 Intact RR2 PRO TM and non-Bt RR BMX Potencia ${ }^{\circledR}$, constituting the two treatments in two different locations. The crop was sown on October 22, 2011 and October 29, 2011 at Farm Rincão Porã and Farm Boa Sorte, respectively, with a density of 15 seeds per meter, thus maintaining a plant population of approximately 300.000 plants ha $\mathrm{a}^{-1}$. The row spacing was 0.50 meters. For fertilizer application in both cultivars, $300 \mathrm{~kg} \mathrm{ha}^{-1}$ of NPK formulation (2:18:18) were used. We carried out the weed and disease control with application of herbicides and fungicides. No insecticides were carried out in the areas studied.

The spatial distribution of adults and nymphs of the stink E. heros was evaluated in two regions (Dourados and Douradina) in two fields each containing of 100 plots in each area, each plot consisted of 11 rows with $5 \mathrm{~m}$ long, totaling $\left(27.5 \mathrm{~m}^{2}\right)$ with $\mathrm{Bt}$ and non-Bt soybean constituting two treatments. Sampling methodology used was the method of cloth-to-beat, consisting of two sticks of wood connected with a white cloth, with a length of $1 \mathrm{~m}$ and width of $1.4 \mathrm{~m}$. For the samples, one end of cloth was placed between the rows of soybeans, being adjusted to the base of a row of plants and other plants extended over the adjacent row. The plants of a row $\left(0.50 \mathrm{~m}^{2}\right)$ were shaken vigorously in order to bring down the pest insects on the cloth (Sturmer et al., 2012). Samples were taken at 7, 14, $21,28,35,42,49,56,63,70,77,84,91,98$ days after emergence (DAE) in Bt and non-Bt soybean.

For data analysis, the mean and variance of the number of adults and nymphs of $E$. heros per plot were obtained at each sampling date, using the relationship between those values as an indicator of the spatial distribution (Elliott, 1979). The dispersion indexes, as described below, were calculated using the Excel program.

Variance/mean ratio: ratio between the variance and mean $\left(I=\mathrm{s}^{2} / \mathrm{m}\right)$, used to measure the deviation of a random arrangement of conditions, where values equal to unity indicates random spatial distribution, values smaller than unity uniform distribution and values greater than the aggregate distribution unit (Rabinovich, 1980). The departure from randomness can be tested using the chi-square test with $n-1$ degrees of freedom, $\chi^{2}=(n-1) \mathrm{s}^{2} / \mathrm{m}$ (Elliott, 1979).

Morisita index: the index of Morisita $\left(I_{\delta}\right)$ is relatively independent of the medium and the number of samples. So when $I_{\delta}=1$ the distribution is random, when $I_{\delta}>1$ the distribution is contagious type of $I_{\delta}$ and when $<1$ indicates a regular distribution (Morisita, 1962). 
Exponent $\mathrm{k}$ of the Negative Binomial distribution: the exponent $\mathrm{k}$ is a suitable dispersion index when the size and numbers of sample units are the same in each sample, as often this is influenced by the size of the sampling units. This parameter is an inverse measure of the degree of aggregation in this case negative values indicate a regular or uniform distribution, positive, values close to zero indicate aggregate provision and higher values indicate a willingness to eight randomly (Pielou, 1977; Southwood, 1978; Elliot, 1979). On this point, Poole (1974) uses another interpretation for it when $0<\mathrm{k}<8$, the index indicates a clustered distribution, and when $0>\mathrm{k}>8$ points to random distribution.

Theoretical frequency distribution: used to evaluate the spatial distribution of the observed species. As presented below, according to L. J. Young and J. H. Young (1998). Poisson distribution: also known as random distribution, characterized by having variance equal to the mean $\left(m=\mathrm{s}^{2}\right)$.

Positive Binomial Distribution: describes the uniform distribution and has less than average $\left(\mathrm{s}^{2}<\mathrm{m}\right)$ variance.

Negative binomial distribution: has higher than average variance, thus indicating clumped distribution, and has two parameters: the mean $(\mathrm{m})$ and the parameter $\mathrm{k}(\mathrm{k}>0)$.

Chi-square test of grip: for checking the fit of the data collected in the field to the theoretical frequency distribution test, we used the chi-square test that compares the total grip of the observed frequencies in the sampled area, with frequencies expected according to L. J. Young and J. H. Young (1998); those frequencies being defined by the product of the probabilities of each class and the total number of sampling units used. To conduct those tests, we chose to fix a minimum expected frequency equal to unity. Statistical analysis was performed using chi-square test at 1 and $5 \%$ probability test.

\section{Results and Discussion}

The presence of adults of $E$. heros on soybean plants in Dourados were detected at 35 days after emergence (DAE) in soybean, Bt and non-Bt in Dourados and Douradina (Figure 1A and 1B). The presence of the stink bug in the vegetative phase is due to the fact that often these bugs initiate colonization of crops at the end of the growing season and early flowering. At that time, the bugs come out of diapause or alternative hosts and migrate to soybean, progressively increasing their populations during the breeding phase (Corrêa-Ferreira, 2005).
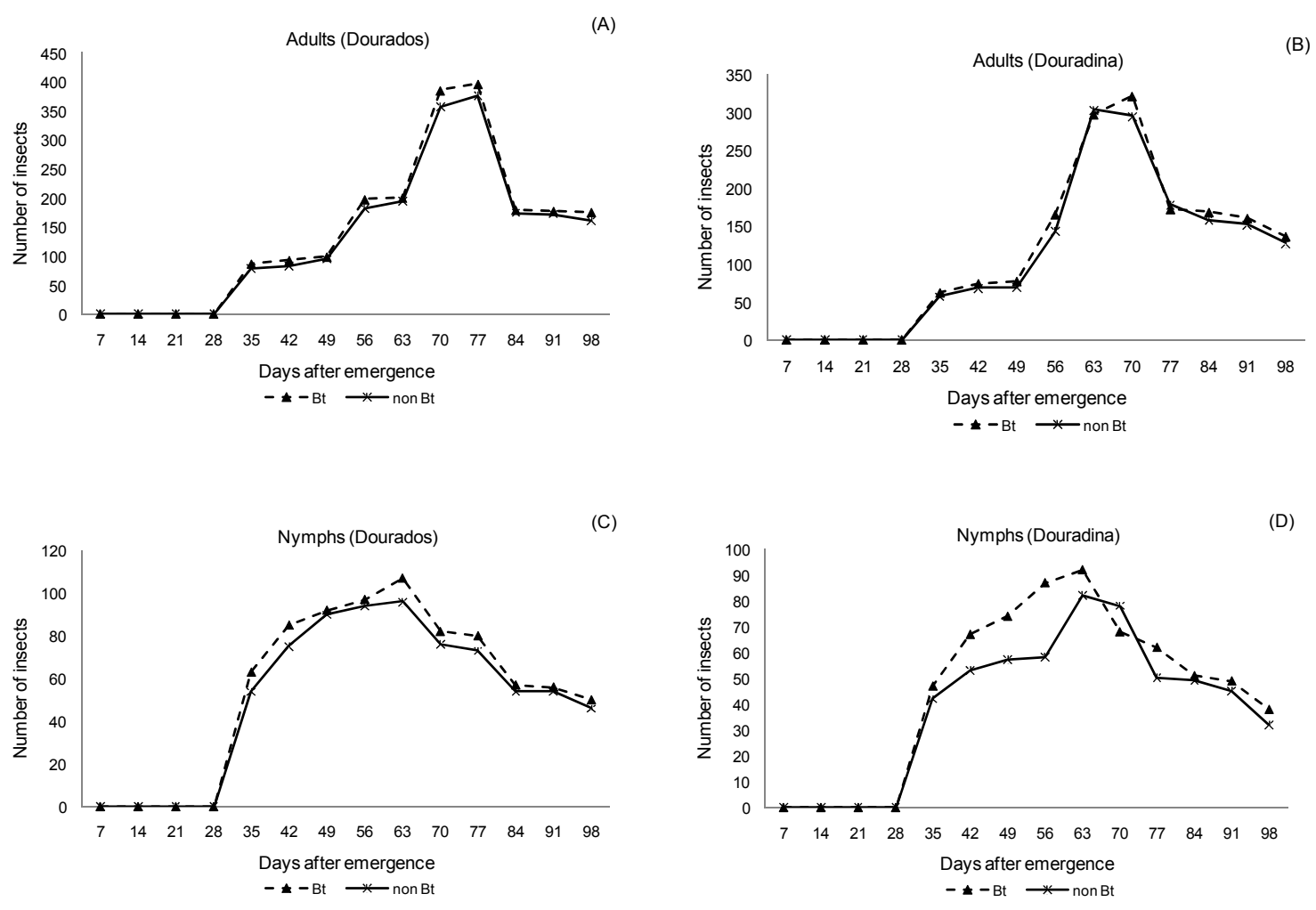

Figure 1. Percentage of the number of adults and nymphs of Euschistus heros occurring in Bt and non-Bt soybean $[$ Glycine $\max (\mathrm{L})]$ as a function of days after emergence in Dourados and Douradina, Mato Grosso do Sul, Brazil, 2012 
In 14 samples, a total of 3856 insects were found, with $51.47 \%$ to $48.52 \%$ cultivating Bt and non-Bt in Dourados for a total of 3181 insects, being $51.30 \%$ for the Bt cultivar and $48.69 \%$ in the non-Bt in Douradina (Figure $1 \mathrm{~A}$ and 1B). The peak population of adults was observed at 77 DAE (January) in Bt and non-Bt soybean, in Dourados and Douradina, respectively (Figure 1A and 1B).

The presence of nymphs of E. heros was observed in Bt and non-Bt soybean from the fifth sample, 35 DAE in both regions (Figure 1C and 1D). The largest numbers of nymphs of E. heros were found in Bt soybeans, which represented 51.92\% of total plots sampled in Dourados, and 53.76\% in Douradina (Figure 1C and 1D). The results observed in the present study corroborate studies by Thomazoni et al. (2010), Dutra et al. (2012b) which showed that Bt technology had greater abundance of this insect.

The highest population density of adults and nymphs of E. heros found in Bt soybean was due probably to the reduction of inter-specific competition between the various populations that made up the community of arthropods culture, it was caused probably due to reduced caterpillar population as the major defoliating caterpillars culture as velvetbean caterpillar Anticarsia gemmatalis (Hübner, 1818), false-medideira caterpillar Chrysodeixis includens (Walker, 1857), Rachiplusia nu (Guenée, 1852) and drill underarm Crocidosema aporema (Walsingham, 1914), those species targeted by toxin CrylAc and therefore were not found in this cultivation because of the resistance offered by such transgenic plants to those Lepidoptera insects (Bernardi et al., 2012).

No preference of adults and nymphs of E. heros was observed in relation cultivars versus regions for $\mathrm{Bt}$ and non-Bt soybean. The similar behavior in the two regions is due to the fact of using the same system of agricultural cultivation in recent years. According to Smaniotto and Panizzi (2013) adopted different cultivation practices, especially tillage and sowing in the second season, which resulted in significant changes in the dynamics of agricultural pests, thus the similarities of the study areas resulted in the same behaviour of E. heros in both regions.

Compared to the aggregation of adults of E. heros, the variance/mean $(I)$ calculated in cultivating Bt presented nine surveys in Dourados and four in Douradina, with statistically higher values indicating that the unit aggregation, and had two samplings in the Bt soybean, with values ranging unit indicating uniformity (Table 1).

In Dourados for adults of $E$. heros soy non-Bt index $I$ had seven samples with statistically higher values than unity (aggregate score). In Douradina index $I$ had four samples with statistically higher values than unity (aggregate score) and two values equal to unity indicating uniform (Table 1) theoretical distribution. Pereira et al. (2004) studied the population of pests in legumes and found regular or uniform distribution of individuals in the population sampled.

In summary, the results of Morisita index $\left(I_{\delta}\right)$ for the treatment $\mathrm{Bt}, E$. heros adults, showed that the largest unit of a total of ten values, eight samples in Dourados and five in Douradina representing an aggregate score. Analyzing the test Morista $\left(I_{\delta}\right)$ index to the non-Bt soybean in Dourados was observed ten samples, seven values were greater than unity (aggregate score); soybeans in Dourados not Bt, and observed in Douradina ten samples, four values were greater than unity and equal to the sampling unit, ie indicated uniformity (Table 1).

Analyzing the exponent $\mathrm{K}$ for Bt soybeans in Dourados, found the ten samples, eight showed aggregate provision for adults of E. heros, because the values were variable from 1.961 to 5.091, and two samples indicated random arrangement with values 10.822 and 33.000. In Douradina was found for K, soy Bt four samples which showed aggregated arrangement of four uniform random and two (Table 1).

It was found for adults of E. heros in non-Bt soybeans in Dourados with ten samples in the field, eight of them indicated aggregate provision for adults, and two showed random distribution. In Douradina we observed five available samples showed aggregated two random three uniform dispersion of the index K (Table 1).

Based on the dispersion index $\mathrm{K}$, it can be stated with certainty that the spatial distribution of E. heros is aggregated, corroborating the results obtained by Bueno et al. (2008) and Souza et al. (2011) in soybean with studies of spatial distribution of the small green stink (Fonseca et al., 2013a) in cotton with studies of spatial distribution of bedbug Piezodorus guildine. 
Table 1. Dispersion indices for adults of Euschistus heros in Bt and non-Bt soybean [Glicine max (L)] function of days after emergence in Dourados and Douradina, Mato Grosso do Sul, Brazil, 2012

\begin{tabular}{|c|c|c|c|c|c|c|c|c|c|c|c|c|}
\hline & \multicolumn{2}{|c|}{ Samples } & \multicolumn{5}{|c|}{ Dourados } & \multicolumn{5}{|c|}{ Douradina } \\
\hline & Numbers & (DAE) & Média & $\mathrm{S}^{2}$ & $I$ & $I_{\delta}$ & $K$ & Média & $\mathrm{S}^{2}$ & $I$ & $I_{\delta}$ & $K$ \\
\hline \multirow{14}{*}{ 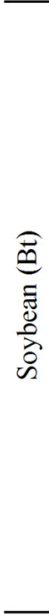 } & $1^{\text {rd }}$ & 7 & 0.000 & - & - & - & - & 0.000 & - & - & - & - \\
\hline & $2^{\text {rd }}$ & 14 & 0.000 & - & - & - & - & 0.000 & - & - & - & - \\
\hline & $3^{\text {rd }}$ & 21 & 0.000 & - & - & - & - & 0.000 & - & - & - & - \\
\hline & $4^{\text {rd }}$ & 28 & 0000 & - & - & - & - & 0.000 & - & - & - & - \\
\hline & $5^{\text {rd }}$ & 35 & 0.860 & 1.051 & $1.222 *$ & $1.259^{\mathrm{NS}}$ & $3.874^{\mathrm{AG}}$ & 0.620 & 0.521 & $0.905^{\mathrm{NS}}$ & $0.846^{\mathrm{NS}}$ & $-6.539^{\mathrm{UN}}$ \\
\hline & $6^{\text {rd }}$ & 42 & 0.920 & 1.226 & $1.332 *$ & $1.362 *$ & $2.767^{\mathrm{AG}}$ & 0.740 & 0.800 & $1.082^{\mathrm{NS}}$ & $1.111^{\mathrm{NS}}$ & $9.069^{\mathrm{AL}}$ \\
\hline & $7^{\text {rd }}$ & 49 & 0.980 & 1.474 & $1.504 *$ & $1.515 *$ & $1.943^{\mathrm{AG}}$ & 0.770 & 0.846 & $1.098^{\mathrm{NS}}$ & $1.128 *$ & $7.847^{\mathrm{AG}}$ \\
\hline & $8^{\text {rd }}$ & 56 & 1970 & 3.949 & $2.004 *$ & $1.507 *$ & $1.961^{\mathrm{AG}}$ & 1.650 & 3.260 & $1.976 *$ & $1.589 *$ & $1.691^{\mathrm{AG}}$ \\
\hline & $9^{\text {rd }}$ & 63 & 2.000 & 2.121 & $1.061^{\mathrm{NS}}$ & $1.030^{\mathrm{NS}}$ & $33.000^{\mathrm{AL}}$ & 2.970 & 3.080 & $1.037^{\mathrm{NS}}$ & $1.012^{\mathrm{NS}}$ & $80.264^{\mathrm{AL}}$ \\
\hline & $10^{\text {rd }}$ & 70 & 3850 & 5.220 & $1.356 *$ & $1.092 *$ & $10.822^{\mathrm{AL}}$ & 3.210 & 4.087 & $1.273 *$ & $1.085 *$ & $11.752^{\mathrm{AL}}$ \\
\hline & $11^{\mathrm{rd}}$ & 77 & 4000 & 7.143 & $1.786 *$ & $1.207 *$ & $5.091^{\mathrm{AG}}$ & 1.720 & 1.335 & $0.776^{\mathrm{NS}}$ & $0.870^{\mathrm{NS}}$ & $-7.683^{\mathrm{UN}}$ \\
\hline & $12^{\text {rd }}$ & 84 & 1.790 & 2.895 & $1.617 *$ & $1.343 *$ & $2.900^{\mathrm{AG}}$ & 1.680 & 2.624 & $1.562 *$ & $1.333 *$ & $2.990^{\mathrm{AG}}$ \\
\hline & $13^{\text {rd }}$ & 91 & 1.770 & 2947 & $1.665 *$ & $1.374 *$ & $2.663^{\mathrm{AG}}$ & 1600 & 2646 & $1.654 *$ & $1.407 *$ & $2.446^{\mathrm{AG}}$ \\
\hline & $14^{\text {rd }}$ & 98 & 1.750 & 2.856 & $1.632 *$ & $1.360 *$ & $2.769^{\mathrm{AG}}$ & 1.360 & 1.465 & $1.077^{\mathrm{NS}}$ & $1.057^{\mathrm{NS}}$ & $17.607^{\mathrm{AL}}$ \\
\hline \multirow{14}{*}{ 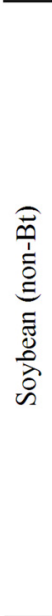 } & $1^{\text {rd }}$ & 7 & 0.000 & - & - & - & - & 0.000 & - & - & - & - \\
\hline & $2^{\text {rd }}$ & 14 & 0.000 & - & - & - & - & 0.000 & - & - & - & - \\
\hline & $3^{\text {rd }}$ & 21 & 0.000 & - & - & - & - & 0.000 & - & - & - & - \\
\hline & $4^{\text {rd }}$ & 28 & 0.000 & - & - & - & - & 0.000 & - & - & - & - \\
\hline & $5^{\text {rd }}$ & 35 & 0.790 & 0.875 & $1.107^{\mathrm{NS}}$ & $1.136^{\mathrm{NS}}$ & $7.373^{\mathrm{AG}}$ & 0.570 & 0.551 & $0.966^{\mathrm{NS}}$ & $0.940^{\mathrm{NS}}$ & $-16.753^{\mathrm{UN}}$ \\
\hline & $6^{\text {rd }}$ & 42 & 0830 & 1.052 & $1.267 *$ & $1.322 *$ & $3.109^{\mathrm{AG}}$ & 0.680 & 0.705 & $1.036^{\mathrm{NS}}$ & $1.054^{\mathrm{NS}}$ & $18.761^{\mathrm{AL}}$ \\
\hline & $7^{\text {rd }}$ & 49 & 0.940 & 1.390 & $1.479 *$ & $1.510 *$ & $1.962^{\mathrm{AG}}$ & 0.690 & 0.822 & $1.191^{\mathrm{NS}}$ & $1.279 *$ & $3.604^{\mathrm{AG}}$ \\
\hline & $8^{\text {rd }}$ & 56 & 1.820 & 3.038 & $1.669 *$ & $1.366 *$ & $2.720^{\mathrm{AG}}$ & 1.430 & 1.763 & $1.233 *$ & $1.162^{\mathrm{NS}}$ & $6.146^{\mathrm{AG}}$ \\
\hline & $9^{\text {rd }}$ & 63 & 1.950 & 2.008 & $1.030^{\mathrm{NS}}$ & $1.015^{\mathrm{NS}}$ & $66.043^{\mathrm{AL}}$ & 3.030 & 5.423 & $1.790 *$ & $1.259 *$ & $3.836^{\mathrm{AG}}$ \\
\hline & $10^{\mathrm{rd}}$ & 70 & 3.560 & 4.229 & $1.188^{\mathrm{NS}}$ & $1.052^{\mathrm{NS}}$ & $18.953^{\mathrm{AL}}$ & 2.940 & 3.128 & $1.064^{\mathrm{NS}}$ & $1.022^{\mathrm{NS}}$ & $46.056^{\mathrm{AL}}$ \\
\hline & $11^{\text {rd }}$ & 77 & 3760 & 5.679 & $1.510 *$ & $1.135 *$ & $7.366^{A G}$ & 1.780 & 1.567 & $0.880 *$ & $0.933^{\mathrm{NS}}$ & $-14.894^{\mathrm{UN}}$ \\
\hline & $12^{\text {rd }}$ & 84 & 1.740 & 2.720 & $1.563 *$ & $1.322 *$ & $3.091^{\mathrm{AG}}$ & 1.580 & 2.347 & $1.485 *$ & $1.306 *$ & $3.254^{\mathrm{AG}}$ \\
\hline & $13^{\text {rd }}$ & 91 & 1720 & 2.749 & $1.598 *$ & $1.346 *$ & $2.875^{\mathrm{AG}}$ & 1.520 & 2.454 & $1.615 *$ & $1.403 *$ & $2.473^{\mathrm{AG}}$ \\
\hline & $14^{\mathrm{rd}}$ & 98 & 1600 & 2.040 & $1.275 *$ & $1.171 *$ & $5.813^{\mathrm{AG}}$ & 1.270 & 1.250 & $0.984 *$ & $0.987 *$ & $-79.048^{\mathrm{UN}}$ \\
\hline
\end{tabular}

*Not significant at 5\% probability. DAE= days after (plant) emergence.

Not significant at $5 \%$ probability.

${ }^{\mathrm{Ag}}$ gregate; ${ }^{\mathrm{UN}}$ uniform; ${ }^{\mathrm{AL}}$ random.

$\mathrm{S}^{2}$ Variance, $I$ Mean-variance ratio, $I_{\delta}$ Morisita index, $K$ Exponent of the negative binominal.

Compared to aggregation nymphs of $E$. heros variance/mean $(I)$ ratio calculated in cultivating Bt presented eight samples in Dourados, seven in Douradina, with statistically higher values indicating the unit aggregation (Table 2).

In non-Bt soybeans in the index $I$ in Dourados nymphs of $E$. heros had seven samples with statistically higher values than unity (aggregate score). In Douradina index $I$ had six samples with statistically higher values than unity (aggregate score) (Table 2).

As most phytophagous Pentatomidae, associated with soybean species tend to be polyphagous (Slansky Jr, \& Panizzi, 1987), which develop in over 32 plant species, although survival and cycle time are influenced by food (Medeiros \& Megier, 2009). Although the dietary patterns of phytophagous bugs, notes the existence of food preferences in localized populations in which insects can act as a oligophagous even monophagous, depending on the availability of hosts (Panizzi, 1997; Cividanes \& Parra., 1994) . 
In summary, the results of Morisita index $\left(I_{\delta}\right)$ for the treatment Bt nymphs of $E$. heros was arranged in aggregate in nine samples in Dourados and Douradina in seven samples, a total of ten. Analyzing the test Morista $\left(I_{\delta}\right)$ index for the non-Bt crop in Dourados, observed ten samples, nine of which had values greater than unity (aggregation); Douradina in, there was the ten samples, seven, was mixed added (Table 2). In this context according to Ricklefs (2003) the spatial arrangement of populations of insects such a standard that can be random uniform and aggregated basis.

Analyzing the exponent $\mathrm{K}$ for nymphs on soybean $\mathrm{Bt}$ found in both regions of the ten samples, all indicated aggregate provision. It was found in soybean fields in both non-Bt ten samples in the field, most of them showed aggregated to the nymphs, and a sample arrangement shown in Douradina randomized, (49 DAE) the dispersion index K (Table 2). These results agree with Maruyama et al. (2002), mentioning the fact that the provision of insects in general tends to aggregate in the field normally.

Table 2. Dispersion indexes nymphs of Euschistus heros in Bt and non-Bt soybean [Glicine max (L)] function of days after emergence in Dourados and Douradina, Mato Grosso do Sul, Brazil, 2012

\begin{tabular}{|c|c|c|c|c|c|c|c|c|c|c|c|c|}
\hline & \multicolumn{2}{|c|}{ Samples } & \multicolumn{5}{|c|}{ Dourados } & \multicolumn{5}{|c|}{ Douradina } \\
\hline & Numbers & (DAE) & Média & $\mathrm{S}^{2}$ & $I$ & $I_{\delta}$ & $K$ & Média & $S^{2}$ & $I$ & $I_{\delta}$ & $K$ \\
\hline \multirow{14}{*}{ 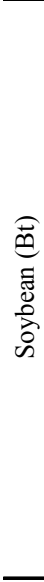 } & $1^{\text {rd }}$ & 7 & 0.000 & - & - & - & - & 0.000 & - & - & - & - \\
\hline & $2^{\text {rd }}$ & 14 & 0.000 & - & - & - & - & 0.000 & - & - & - & - \\
\hline & $3^{\text {rd }}$ & 21 & 0.000 & - & - & - & - & 0.000 & - & - & - & - \\
\hline & $4^{\text {rd }}$ & 28 & 0.000 & - & - & - & - & 0.000 & - & - & - & - \\
\hline & $5^{\text {rd }}$ & 35 & 0.630 & 1.064 & $1.688 *$ & $2.099 *$ & $0.915^{\mathrm{AG}}$ & 0.470 & 0.555 & $1.180^{\mathrm{NS}}$ & $1.388^{\mathrm{NS}}$ & $2.610^{\mathrm{AG}}$ \\
\hline & $6^{\text {rd }}$ & 42 & 0.850 & 2.169 & $2.552 *$ & $2.829 *$ & $0.548^{\mathrm{AG}}$ & 0.670 & 0.991 & $1.479 *$ & $1.719 *$ & $1.398^{\mathrm{AG}}$ \\
\hline & $7^{\text {rd }}$ & 49 & 0.920 & 1.953 & $2.123 *$ & $2.222 *$ & $0.819^{\mathrm{AG}}$ & 0.740 & 0.821 & $1.109^{\mathrm{NS}}$ & $1.148^{\mathrm{NS}}$ & $6.794^{\mathrm{AG}}$ \\
\hline & $8^{\text {rd }}$ & 56 & 0.970 & 1.686 & $1.738 *$ & $1.761 *$ & $1.314^{\mathrm{AG}}$ & 0.870 & 1.266 & $1.455 *$ & $1.524 *$ & $1.913^{\mathrm{AG}}$ \\
\hline & $9^{\text {rd }}$ & 63 & 1.070 & 2.288 & $2.138 *$ & $2.063 *$ & $0.940^{\mathrm{AG}}$ & 0.920 & 1.893 & $2.057 *$ & $2.150 *$ & $0.870^{\mathrm{AG}}$ \\
\hline & $10^{\text {rd }}$ & 70 & 0.820 & 1.866 & $2.276 *$ & $2.559 *$ & $0.643^{\mathrm{AG}}$ & 0.680 & 1.068 & $1.571 *$ & $1.844 *$ & $1.191^{\mathrm{AG}}$ \\
\hline & $11^{\text {rd }}$ & 77 & 0.800 & 1.697 & $2.121 *$ & $2.405 *$ & $0.714^{\mathrm{AG}}$ & 0.620 & 0.844 & $1.361 *$ & $1.586 *$ & $1.716^{\mathrm{AG}}$ \\
\hline & $12^{\text {rd }}$ & 84 & 0.570 & 0.773 & $1.356 *$ & $1.629 *$ & $1.602^{\mathrm{AG}}$ & 0.510 & 0.717 & $1.406 *$ & $1.804 *$ & $1.256^{\mathrm{AG}}$ \\
\hline & $13^{\text {rd }}$ & 91 & 0.560 & 0.714 & $1.274^{\mathrm{NS}}$ & 1.494 * & $2.043^{\mathrm{AG}}$ & 0.490 & 0.677 & $1.381 *$ & $1.786 *$ & $1.286^{\mathrm{AG}}$ \\
\hline & $14^{\text {rd }}$ & 98 & 0.500 & 0.576 & $1.152^{\mathrm{NS}}$ & $1.306^{\mathrm{NS}}$ & $3.300^{\mathrm{AG}}$ & 0.380 & 0.460 & $1.211^{\mathrm{NS}}$ & $1.565^{\mathrm{NS}}$ & $1.800^{\mathrm{AG}}$ \\
\hline \multirow{14}{*}{ 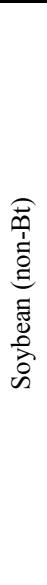 } & $1^{\text {rd }}$ & 7 & 0.000 & - & - & - & - & 0.000 & - & - & - & - \\
\hline & $2^{\text {rd }}$ & 14 & 0.000 & - & - & - & - & 0.000 & - & - & - & - \\
\hline & $3^{\text {rd }}$ & 21 & 0.000 & - & - & - & - & 0.000 & - & - & - & - \\
\hline & $4^{\text {rd }}$ & 28 & 0.000 & - & - & - & - & 0.000 & - & - & - & - \\
\hline & $5^{\text {rd }}$ & 35 & 0.540 & 0.695 & $1.288^{\mathrm{NS}}$ & $1.537 *$ & $1.877^{\mathrm{AG}}$ & 0.420 & 0.509 & $1.211^{\mathrm{NS}}$ & $1.510^{\mathrm{NS}}$ & $1.989^{\mathrm{AG}}$ \\
\hline & $6^{\text {rd }}$ & 42 & 0.750 & 1.260 & $1.680 *$ & $1.910 *$ & $1.103^{\mathrm{AG}}$ & 0.530 & 0.656 & $1.237^{\mathrm{NS}}$ & $1.451^{\mathrm{NS}}$ & $2.235^{\mathrm{AG}}$ \\
\hline & $7^{\text {rd }}$ & 49 & 0.900 & 1.970 & $2.189 *$ & $2.322 *$ & $0.757^{\mathrm{AG}}$ & 0.570 & 0.571 & $1.001^{\mathrm{NS}}$ & $1.003^{\mathrm{NS}}$ & $402.064^{\mathrm{AL}}$ \\
\hline & $8^{\text {rd }}$ & 56 & 0.940 & 1.411 & $1.501 *$ & $1.533 *$ & $1.878^{\mathrm{AG}}$ & 0.580 & 0.771 & $1.330 *$ & $1.573 *$ & $1.758^{\mathrm{AG}}$ \\
\hline & $9^{\text {rd }}$ & 63 & 0.960 & 1.958 & $2.040 *$ & $2.083 *$ & $0.923^{\mathrm{AG}}$ & 0.820 & 1.684 & 2.054 * & $2.288 *$ & $0.778^{\mathrm{AG}}$ \\
\hline & $10^{\text {rd }}$ & 70 & 0.760 & 1.457 & 1.917 * & $2.211 *$ & $0.829^{\mathrm{AG}}$ & 0.780 & 1.668 & $2.139 *$ & $2.464 *$ & $0.685^{\mathrm{AG}}$ \\
\hline & $11^{\text {rd }}$ & 77 & 0.730 & 1.290 & $1.767 *$ & $2.055 *$ & $0.952^{\mathrm{AG}}$ & 0.500 & 0.677 & 1.354 * & $1.714 *$ & $1.414^{\mathrm{AG}}$ \\
\hline & $12^{\text {rd }}$ & 84 & 0.540 & 0.736 & $1.363 *$ & $1.677 *$ & $1.490^{\mathrm{AG}}$ & 0.490 & 0.656 & $1.340 *$ & $1.701 *$ & $1.442^{\mathrm{AG}}$ \\
\hline & $13^{\text {rd }}$ & 91 & 0.540 & 0.695 & $1.288^{\mathrm{NS}}$ & $1.537 *$ & $1.877^{\mathrm{AG}}$ & 0.450 & 0.593 & 1.319 * & $1.717 *$ & $1.412^{\mathrm{AG}}$ \\
\hline & $14^{\text {rd }}$ & 98 & 0.460 & 0.514 & $1.116^{\mathrm{NS}}$ & $1.256^{\mathrm{NS}}$ & $3.953^{\mathrm{AG}}$ & 0.320 & 0.402 & $1.255^{\mathrm{NS}}$ & $1.815 *$ & $1.255^{\mathrm{AG}}$ \\
\hline
\end{tabular}

*Not significant at $5 \%$ probability. DAE= days after (plant) emergence.

Not significant at $5 \%$ probability.

${ }^{\mathrm{Ag}}$ gregate; ${ }^{\mathrm{UN}}$ uniform; ${ }^{\mathrm{AL}}$ random.

$\mathrm{S}^{2}$ Variance, $I$ Mean-variance ratio, $I_{\delta}$ Morisita index, $K$ Exponent of the negative binominal.

Tests of theoretical frequency distributions of adults of E. heros, with ten samples showed, sufficient numbers of classes to perform the adjustment test for Bt soybean in Douradina and Dourados (Table 3). Melo et al. (2006) and 
Fonseca et al. (2013c) studied the distribution of pests and conducted theoretical frequency distributions for insect pests in eight to 12 samples in field.

The values of adults of E. heros to Bt and non-Bt soybean in Dourados and Douradina indicate that the data fitted to theoretical models of the Poisson distribution (random arrangement) negative binomial (aggregate score) and positive binomial (uniform set) in the samples (Table 3).

According to Degrande (1998), Fonseca et al. (2013a) insect begin the dispersion later in the areas of soybeans and over time the distribution becomes widespread throughout the field.

Table 3. Chi-square test of adherence by the expected Poisson distributions, negative binomial (Bn) positive binomial (Bp), spatial arrangement for Euschistus heros in Bt and non-Bt soybean [Glicine max (L)] frequencies in the days after emergence in Dourados and Douradina, Mato Grosso do Sul, Brazil , 2012

\begin{tabular}{|c|c|c|c|c|c|c|c|c|c|c|}
\hline & \multicolumn{2}{|c|}{ Samples } & \multicolumn{3}{|c|}{ Dourados } & \multirow{2}{*}{ 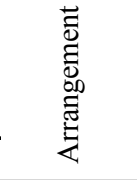 } & \multicolumn{3}{|c|}{ Douradina } & \multirow{2}{*}{ 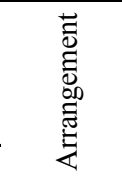 } \\
\hline & Numbers & (DAE) & Poisson & $\mathrm{Bn}$ & $\mathrm{Bp}$ & & Poisson & $\mathrm{Bn}$ & $\mathrm{Bp}$ & \\
\hline \multirow{14}{*}{ 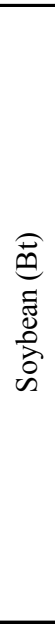 } & $1^{\text {rd }}$ & 7 & $\mathrm{i}$ & $\mathrm{i}$ & $\mathrm{i}$ & \multirow{4}{*}{ NP } & $\mathrm{i}$ & $\mathrm{i}$ & $\mathrm{i}$ & \multirow{4}{*}{ NP } \\
\hline & $2^{\mathrm{rd}}$ & 14 & $\mathrm{i}$ & $\mathrm{i}$ & $\mathrm{i}$ & & $\mathrm{i}$ & $\mathrm{i}$ & $\mathrm{i}$ & \\
\hline & $3^{\text {rd }}$ & 21 & $\mathrm{i}$ & $\mathrm{i}$ & $\mathrm{i}$ & & $\mathrm{i}$ & $\mathrm{i}$ & $\mathrm{i}$ & \\
\hline & $4^{\mathrm{rd}}$ & 28 & $\mathrm{i}$ & i & $\mathrm{i}$ & & $\mathrm{i}$ & $\mathrm{i}$ & $\mathrm{i}$ & \\
\hline & $5^{\mathrm{rd}}$ & 35 & $7.959 *$ & $8.753^{\mathrm{NS}}$ & $4.021 *$ & \multirow{3}{*}{ 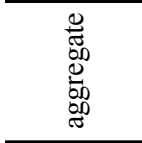 } & $8.292 *$ & $10.626^{\mathrm{NS}}$ & $9.249 * *$ & \multirow{3}{*}{ 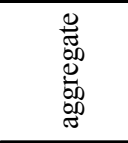 } \\
\hline & $6^{\mathrm{rd}}$ & 42 & $10.391 *$ & $6.380^{\mathrm{NS}}$ & $9.078 *$ & & $11.121 *$ & $8.941^{\mathrm{NS}}$ & $12.805 * *$ & \\
\hline & $7^{\text {rd }}$ & 49 & $17.702 *$ & $5.578^{\mathrm{NS}}$ & $14.304 *$ & & $11.702 * *$ & $8.733^{\mathrm{NS}}$ & $13.485 * *$ & \\
\hline & $8^{\text {rd }}$ & 56 & $4.927^{\mathrm{NS}}$ & $20.303 *$ & $8.215 *$ & \multirow{4}{*}{ 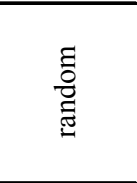 } & $1.402^{\mathrm{NS}}$ & $20.034 * *$ & $3.090 *$ & \multirow{3}{*}{ 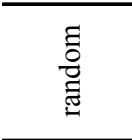 } \\
\hline & $9^{\mathrm{rd}}$ & 63 & $4.324^{\mathrm{NS}}$ & $36.911 *$ & $9.288 *$ & & $2.804^{\mathrm{NS}}$ & $45.906 * *$ & $5.501 *$ & \\
\hline & $10^{\mathrm{rd}}$ & 70 & $7.018^{\mathrm{NS}}$ & $27.337 *$ & $21.566 *$ & & $21.679^{\mathrm{NS}}$ & $42.482 * *$ & $63.059 * *$ & \\
\hline & $11^{\mathrm{rd}}$ & 77 & $46.555^{\mathrm{NS}}$ & $18.219 *$ & $243.730 *$ & & $10.639 *$ & $48.747 * *$ & $10.532^{\mathrm{NS}}$ & uniform \\
\hline & $12^{\mathrm{rd}}$ & 84 & $9.098 *$ & $12.246 *$ & $7.468^{\mathrm{NS}}$ & \multirow{3}{*}{$\stackrel{\Xi}{\Xi}$} & $10.556 *$ & $10.460^{\mathrm{NS}}$ & $10.786^{* *}$ & \multirow{2}{*}{ aggregate } \\
\hline & $13^{\mathrm{rd}}$ & 91 & $10.149 *$ & $9.418 *$ & $9.581^{\mathrm{NS}}$ & & $10.596^{\mathrm{NS}}$ & $6.708^{\mathrm{NS}}$ & $13.365 * *$ & \\
\hline & $14^{\mathrm{rd}}$ & 98 & $8.383 *$ & $10.450 *$ & $8.560^{\mathrm{NS}}$ & & $7.595^{\mathrm{NS}}$ & $18.872 * *$ & $11.015 * *$ & random \\
\hline \multirow{14}{*}{ 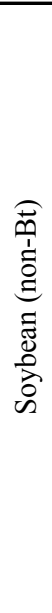 } & $1^{\mathrm{rd}}$ & 7 & $\mathrm{i}$ & $\mathrm{i}$ & $\mathrm{i}$ & \multirow{4}{*}{ NP } & $\mathrm{i}$ & $\mathrm{i}$ & $\mathrm{i}$ & \multirow{4}{*}{ NP } \\
\hline & $2^{\text {rd }}$ & 14 & $\mathrm{i}$ & $\mathrm{i}$ & $\mathrm{i}$ & & $\mathrm{i}$ & $\mathrm{i}$ & $\mathrm{i}$ & \\
\hline & $3^{\text {rd }}$ & 21 & $\mathrm{i}$ & $\mathrm{i}$ & $\mathrm{i}$ & & $\mathrm{i}$ & $\mathrm{i}$ & $\mathrm{i}$ & \\
\hline & $4^{\text {rd }}$ & 28 & $\mathrm{i}$ & $\mathrm{i}$ & $\mathrm{i}$ & & $\mathrm{i}$ & $\mathrm{i}$ & $\mathrm{i}$ & \\
\hline & $5^{\mathrm{rd}}$ & 35 & $5.811 *$ & $8.528^{\mathrm{NS}}$ & $6.184 *$ & \multirow{3}{*}{ 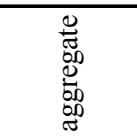 } & $9.101 *$ & $9.752^{\mathrm{NS}}$ & $9.983 * *$ & \multirow{5}{*}{ 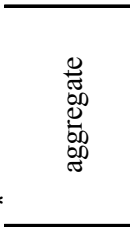 } \\
\hline & $6^{\mathrm{rd}}$ & 42 & $10.020 *$ & $5.303^{\mathrm{ND}}$ & $12.336 *$ & & $17.585 * *$ & $16.021^{\mathrm{NS}}$ & $19.459 * *$ & \\
\hline & $7^{\mathrm{rd}}$ & 49 & $16.095 *$ & $4.674^{\mathrm{NS}}$ & $15.244 *$ & & $15.968 * *$ & $9.915^{\mathrm{NS}}$ & $18.639 * *$ & \\
\hline & $8^{\text {rd }}$ & 56 & $0.817^{\mathrm{NS}}$ & $26.547 *$ & $1.861 *$ & \multirow{3}{*}{ 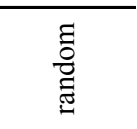 } & $7.267 *$ & $30.933^{\mathrm{NS}}$ & $7.109 * *$ & \\
\hline & $9^{\text {rd }}$ & 63 & $4.974^{\mathrm{NS}}$ & $38.150 *$ & $8.991 *$ & & $123.014 * *$ & $16.990^{\mathrm{NS}}$ & $440.705 * *$ & \\
\hline & $10^{\mathrm{rd}}$ & 70 & $4.918^{\mathrm{NS}}$ & $30.681 *$ & $18.860 *$ & & $8.342^{\mathrm{NS}}$ & $32.821 * *$ & $24.886 * *$ & \multirow{2}{*}{ random } \\
\hline & $11^{\mathrm{rd}}$ & 77 & $41.289 *$ & $26.630^{\mathrm{NS}}$ & $195.420 *$ & aggregate & $6.656^{\mathrm{NS}}$ & $38.551 * *$ & $8.726 * *$ & \\
\hline & $12^{\mathrm{rd}}$ & 84 & $8.169^{\mathrm{NS}}$ & $13.794^{\mathrm{NS}}$ & $7.542 *$ & \multirow{3}{*}{ 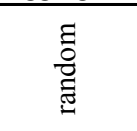 } & $6.530 *$ & $13.297 * *$ & $6.135^{\mathrm{NS}}$ & uniform \\
\hline & $13^{\mathrm{rd}}$ & 91 & $8.804^{\mathrm{NS}}$ & $11.430 *$ & $8.218 *$ & & $7.976^{\mathrm{NS}}$ & $8.929 *$ & $9.578 * *$ & \multirow{2}{*}{ random } \\
\hline & $14^{\mathrm{rd}}$ & 98 & $5.350^{\mathrm{NS}}$ & $15.461 *$ & $8.316 *$ & & $9.383^{\mathrm{NS}}$ & $21.096 * *$ & $10.720 * *$ & \\
\hline
\end{tabular}

\footnotetext{
$* *$ Not significant at $1 \%$ and $*$ significant at $5 \%$ probability. DAE $=$ days after (plant) emergence.

${ }^{n s}$ Not significant at $1 \%$ and $5 \%$ probability.

${ }^{\mathrm{i}}$ Class insufficiently.

${ }^{\mathrm{NP}}$ not present.
} 
Tests of theoretical frequency distributions for nymphs of $E$. heros presented in ten samples, sufficient numbers of classes to perform the adjustment test for Bt soybean in Dourados and Douradina. The values of the nymphs of $E$. heros for Bt cultivar in Dourados and Douradina indicate that the data fitted to theoretical models of the negative binomial distribution (aggregate score) in samples taken (Table 4). The dispersion is probably induced by changes in food availability around the nymphs and competition for food (Panizzi, 1991; Panizi \& Oliveira, 1998).

Brown stink bug nymphs disperse the site of oviposition, however can cover only relatively small distances. For example, small nymphs of the green stink bug, Piezodorus guildinii move up to $12 \mathrm{~m}$ from the starting point during its development in soybean fields. Importantly, the nymphs move more in the longitudinal direction than in the transverse direction of the rows of soybean (Panizzi et al., 1980; Cividanes \& Parra, 1994).

The use of multiple indices of dispersion to calculate the spatial distribution of a pest is an important recommendation (Barbosa, 2003), as a single index does not provide all the attributes considered ideal from statistical point of view, while the use of more than one index can provide greater certainty to conclusions (Martins et al., 2012).

Table 4. Chi-square test of adherence by the expected Poisson distributions, negative binomial (Bn) positive binomial (Bp), spatial arrangement nymphs of Euschistus heros in Bt and non-Bt soybean [Glicine max (L.)] frequencies in the days after emergence inDourados and Douradina, Mato Grosso do Sul, Brazil, 2012

\begin{tabular}{|c|c|c|c|c|c|c|c|c|c|c|}
\hline & \multicolumn{2}{|c|}{ Samples } & \multicolumn{3}{|c|}{ Dourados } & \multirow{2}{*}{ 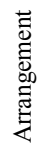 } & \multicolumn{3}{|c|}{ Douradina } & \multirow{2}{*}{ 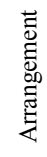 } \\
\hline & Numbers & (DAE) & Poisson & $\mathrm{Bn}$ & $\mathrm{Bp}$ & & Poisson & $\mathrm{Bn}$ & Bp & \\
\hline \multirow{14}{*}{ 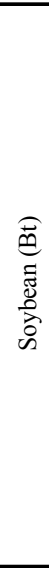 } & $1^{\text {rd }}$ & 7 & $\mathrm{i}$ & $\mathrm{i}$ & $\mathrm{i}$ & \multirow{4}{*}{ NP } & $\mathrm{i}$ & $\mathrm{i}$ & $\mathrm{i}$ & \multirow{4}{*}{$\mathrm{NP}$} \\
\hline & $2^{\text {rd }}$ & 14 & $\mathrm{i}$ & $\mathrm{i}$ & $\mathrm{i}$ & & $\mathrm{i}$ & $\mathrm{i}$ & $\mathrm{i}$ & \\
\hline & $3^{\text {rd }}$ & 21 & $\mathrm{i}$ & $\mathrm{i}$ & $\mathrm{i}$ & & $\mathrm{i}$ & $\mathrm{i}$ & $\mathrm{i}$ & \\
\hline & $4^{\text {rd }}$ & 28 & $\mathrm{i}$ & $\mathrm{i}$ & i & & $\mathrm{i}$ & i & $\mathrm{i}$ & \\
\hline & $5^{\text {rd }}$ & 35 & $20.461 * *$ & $7.458^{\mathrm{NS}}$ & $21.847 * *$ & \multirow{10}{*}{ 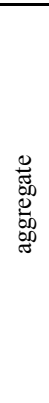 } & $4.502 *$ & $2.518^{\mathrm{NS}}$ & $5.254 *$ & \multirow{10}{*}{ 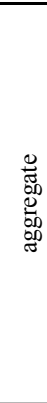 } \\
\hline & $6^{\mathrm{rd}}$ & 42 & $30.310 * *$ & $12.056^{\mathrm{NS}}$ & $29.451 * *$ & & $11.556 * *$ & $4.811^{\mathrm{NS}}$ & $15.652 * *$ & \\
\hline & $7^{\mathrm{rd}}$ & 49 & $11.718^{* *}$ & $7.326^{\mathrm{NS}}$ & $10.364 * *$ & & $5.807 *$ & $7.688^{\mathrm{NS}}$ & $6.018 *$ & \\
\hline & $8^{\text {rd }}$ & 56 & $9.443 *$ & $4.814^{\mathrm{NS}}$ & $11.316^{* *}$ & & $10.248 *$ & $7.230^{\mathrm{NS}}$ & $11.515 * *$ & \\
\hline & $9^{\text {rd }}$ & 63 & $21.138 * *$ & $6.070^{\mathrm{NS}}$ & $25.156 * *$ & & $25.884 * *$ & $8.065^{\mathrm{NS}}$ & $29.092 * *$ & \\
\hline & $10^{\mathrm{rd}}$ & 70 & $30.310 * *$ & $6.738^{\mathrm{NS}}$ & $29.451 * *$ & & $16.840 * *$ & $5.841^{\mathrm{NS}}$ & $21.933 * *$ & \\
\hline & $11^{\text {rd }}$ & 77 & $18.256 * *$ & $3.6704^{\mathrm{NS}}$ & $21.525 * *$ & & $14.142 * *$ & $5.214^{\mathrm{NS}}$ & $15.324 * *$ & \\
\hline & $12^{\text {rd }}$ & 84 & $12.679 * *$ & $4.201^{\mathrm{NS}}$ & $14.136^{* *}$ & & $13.020 * *$ & $3.780^{\mathrm{NS}}$ & $14.752 * *$ & \\
\hline & $13^{\text {rd }}$ & 91 & $7.365 *$ & $2.704^{\mathrm{NS}}$ & $8.514 * *$ & & $10.815 *$ & $3.041^{\mathrm{NS}}$ & $12.480 * *$ & \\
\hline & $14^{\mathrm{rd}}$ & 98 & $7.219 *$ & $5.722^{\mathrm{NS}}$ & 8.038 ** & & $4.133 *$ & $1.815^{\mathrm{NS}}$ & $4.938 *$ & \\
\hline \multirow{14}{*}{ 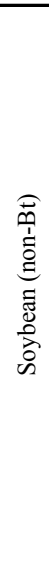 } & $1^{\text {rd }}$ & 7 & $\mathrm{i}$ & $\mathrm{i}$ & $\mathrm{i}$ & \multirow{3}{*}{ NP } & $\mathrm{i}$ & $\mathrm{i}$ & $\mathrm{i}$ & \multirow{3}{*}{ NI } \\
\hline & $2^{\text {rd }}$ & 14 & $\mathrm{i}$ & $\mathrm{i}$ & i & & $\mathrm{i}$ & $\mathrm{i}$ & $\mathrm{i}$ & \\
\hline & $3^{\text {rd }}$ & 21 & $\mathrm{i}$ & i & i & & $\mathrm{i}$ & $\mathrm{i}$ & $\mathrm{i}$ & \\
\hline & $4^{\text {rd }}$ & 28 & $6.219 *$ & $4.434^{\mathrm{NS}}$ & $6.928 * *$ & \multirow{11}{*}{ 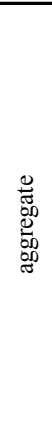 } & $\mathrm{i}$ & i & $\mathrm{i}$ & \multirow{11}{*}{ 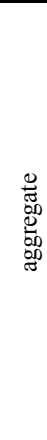 } \\
\hline & $5^{\mathrm{rd}}$ & 35 & $15.124 * *$ & $7.969^{\mathrm{NS}}$ & $16.720 * *$ & & $7.659 *$ & $4.210^{\mathrm{NS}}$ & $8.577^{* *}$ & \\
\hline & $6^{\text {rd }}$ & 42 & $21.950 * *$ & $9.480^{\mathrm{NS}}$ & $29.451 * *$ & & $11.581 * *$ & $6.547^{\mathrm{NS}}$ & $12.628 * *$ & \\
\hline & $7^{\text {rd }}$ & 49 & $16.440 * *$ & $8.466^{\mathrm{NS}}$ & $14.333^{* *}$ & & $3.486 *$ & $6.124^{\mathrm{NS}}$ & $3.847 *$ & \\
\hline & $8^{\text {rd }}$ & 56 & $8.419 *$ & $2.931^{\mathrm{NS}}$ & $9.641^{* *}$ & & $12.370 * *$ & $4.538^{\mathrm{NS}}$ & $13.613 * *$ & \\
\hline & $9^{\text {rd }}$ & 63 & $22.972 * *$ & $5.801^{\mathrm{NS}}$ & $27.462 * *$ & & $25.789 * *$ & $8.908^{\mathrm{NS}}$ & $28.352 * *$ & \\
\hline & $10^{\mathrm{rd}}$ & 70 & $32.222 * *$ & $6.743^{\mathrm{NS}}$ & $31.628 * *$ & & $30.113 * *$ & $9.880^{\mathrm{NS}}$ & $33.317 * *$ & \\
\hline & $11^{\mathrm{rd}}$ & 77 & $22.212 * *$ & $3.790^{\mathrm{NS}}$ & $25.758 * *$ & & $15.695 * *$ & $6.241^{\mathrm{NS}}$ & $17.356 * *$ & \\
\hline & $12^{\text {rd }}$ & 84 & $11.372 * *$ & $3.283^{\mathrm{NS}}$ & $12.975 * *$ & & $9.339 *$ & $2.600^{\mathrm{NS}}$ & $10.730 * *$ & \\
\hline & $13^{\text {rd }}$ & 91 & $7.554 *$ & $2.387^{\mathrm{NS}}$ & $8.745 * *$ & & $7.442 *$ & $1.929^{\mathrm{NS}}$ & $8.743 * *$ & \\
\hline & $14^{\text {rd }}$ & 98 & $3.112 *$ & $2.917^{\mathrm{NS}}$ & $3.666^{\mathrm{NS}}$ & & $3.987 *$ & $1.006^{\mathrm{NS}}$ & $4.900 *$ & \\
\hline
\end{tabular}

$* *$ Not significant at $1 \%$ and $*$ significant at $5 \%$ probability. DAE $=$ days after (plant) emergence.

${ }^{n s}$ Not significant at $1 \%$ and $5 \%$ probability.

${ }^{\mathrm{i}}$ Class insufficiently.

${ }^{\mathrm{NP}}$ not present. 
Adults of $E$. heros are arranged differently between soybean cultivars and between regions, since in both cultivars and locations, individuals of the populations studied showed different patterns of spatial distribution as a function of days after emergence. However, with respect to the spatial arrangement of the nymphs of $E$. heros, it was found that the location of $\mathrm{Bt}$ soybean cultivation and did not influence the distribution, because when analyzing the results obtained from the theoretical frequency distributions, represented by aggregate in both cultivars and in both regions disposal. This result corroborates with the study of Souza et al. (2013) corroborates this work, in which they reported that nymphs of $E$. heros of the first to third instars clumped spatial distribution.

The absence of caterpillars target of Bt soybean seems to have favored the growth of populations of adults and nymphs of $E$. heros in cultivating Bt. Thus, it is suggested that future studies seek to develop sequential samples of this pest in soybean in both the Bt crop cultivation and non-Bt, aiming to define the exact number of sample units to be used.

The precise number of sample units for the sampling process of these insects is extremely important since those species are the direct cause considerable crop losses. Thus the application of insecticides should be performed only in locations where the presence of insect pests and taking into account the principles of integrated pest management and arrangement of spatial distribution. This will result in a more efficient management, with less environmental impact.

\section{Conclusion}

Adults of E. heros are arranged differently for Bt and non-Bt soybean and between regions, since in both cultivars and locations, individuals of the populations evaluated in probabilistic set arrangements negative binomial distribution (aggregate), Poisson (random), and positive binomial distribution (uniform), as the days after soybean emergence.

The nymphs of E. heros showed aggregated spatial arrangement, being distributed similarly for $\mathrm{Bt}$ and non-Bt soybean and regions, setting a negative binomial distribution model.

\section{References}

Barbosa, J. C. (2003). Métodos estatísticos aplicados à entomologia (1st ed., p. 254). Jaboticabal, SP: FUNEP.

Barros, R., \& Degrande, P. E. (2012). Desempenho do algodão-Bt como tática de controle de pragas em condições de campo. Científica, 40(2), 117-137.

Bernardi, O., Malvestiti, G., Dourado, P. M., Oliveira, W. S., Martinelli, S., Berger, G. U., ... Omoto, C. (2012). Assessment of the high-dose concept and level of control provided by MON 87701 x MON 89788 soybean against Anticarsia gemmatalis and Pseudoplusia includens (Lepidoptera: Noctuidae) in Brazil. Pest Management Science, 68, 1083-1091. http://dx.doi.org/10.1002/ps.3271

Bueno, N. M., Christovam, R. S., Prado, E. P., Aguiar Junior, H. O., Dalpogetto, M. H. F. A., \& Raetano, C. G. (2008). Distribuição espacial de Piezodorus guildinii (Hemiptera: Pentatomidae) na cultura da soja. In: XXII Congresso Brasileiro de Entomologia, 2008, Uberlândia. Anais. MG. XXII Congresso Brasileiro de Entomologia.

Cividanes, F. J., \& Parra, J. R. P. (1994). Zoneamento ecológico de Nezara viridula (L.), Piezodorus guildinii (West.) e Euschistus heros (Fabr.) (Heteroptera: Pentatomidae) em quatro estados produtores de soja do Brasil. Jornal Anais da Sociedade Entomológica do Brasil, 23(2), 219-226.

Corrêa-Ferreira B. S. (2005). Susceptibilidade da soja aos percevejos Euschistus heros (F.) e Piezodorus guildinii (West.) na fase anterior ao desenvolvimento das vagens. Pesquisa Agropecuária Brasileira, 40(11), 1067-1072.

Corrêa-Ferreira B. S., \& Panizzi, A. R. (1999). Percevejos da soja e seu manejo. Londrina, PR. Embrapa-Centro Nacional de Pesquisa de Soja. (1st ed, p. 45). (Circular técnica, 24).

Degrande, P. E. (1998). Guia prático de controle das pragas do algodoeiro. (1st ed., p. 60). Dourados, MS. Universidade Federal do Mato Grosso do Sul.

Dutra, C. C., Koch, R. L., Burkness, E., Meissle, M., Romeis, J., Hutchison, W. D., \& Fernandes, M. G. (2012b). Harmonia axyridis (Pallas) (Coleoptera: Coccinellidae) exhibits no preference between Bt and non-Bt maize fed Spodoptera frugiperda (JE Smith) (Lepidoptera: Noctuidae). Plos One, 7(9), e44867. http://dx.doi.org/10.1371/journal.pone.0044867

Dutra, C. C., Meotti, C., Fernandes, M. G., \& Raizer, J. (2012a). Riqueza e composição de espécies de insetos visitantes florais de algodoeiro Bt e não-Bt. Arquivos do Instituto Biológico, 79(3), 353-361. 
Elliott, J. M. (1979). Some methods for the statistical analysis of sample benthic invertebrates. (1 ed., p. 157). Ambleside, Freshwater Biological Association.

Fernandes, M. G., Busoli, A. C., \& Barbosa, J. C. (2003). Distribuição espacial de Alabama argillacea (Hübner) (Lepidoptera: Noctuidae) em algodoeiro. Neotropical Entomology, 32(1), 107-115. http://dx.doi.org/10.1590/S1519-566X2003000100016

Fietz, C. R., \& Fisch, G. F. (2006). O clima da região de Dourados, MS. (1st ed., p. 32). Dourados, MS, Brasil: Embrapa Agropecuária Oeste. (Documentos, 85).

Fonseca, P. R. B., Fernandes, M. G., Cavada, L. H., \& Silva, J. A. N. (2013a). Distribuição espacial de adultos de Piezodorus guildine em algodoeiro Bt e não Bt. Revista de Ciências Exatas e da Terra, 2(2), 71-82.

Fonseca, P. R. B., Fernandes, M. G., Degrande, P. E., Mota, T. A., \& Kassab, S. O. (2013c). Spatial distribution of adult Anthonomus grandis Boheman (Coleoptera: Curculionidae) and buds with feeding punctures on conventional and Bt cotton. Semina. Ciências Agrárias, 34(3), 1129-1138. http://dx.doi.org/10.5433/1679-0359.2013v34n3p1129

Fonseca, P. R. B., Fernandes, M. G., Justiniano, W., Cavada, L. H., \& Silva, J. A. N. (2013b). Leaf Chlorophyll Content and Agronomic Performance of Bt and Non-Bt Soybean. Journal of Agricultural Science, 5(12), 117-125. http://dx.doi.org/10.5539/jas.v5n12p117

Homrich, M. S., Passaglia, L. M. P., Pereira, J. F., Bertagnolli, P. F., Pasquali, G., Zaidi, M. A., ... Zanettini, M. H. B. (2008). Resistance to Anticarsia gemmatalis Hübner (Lepidoptera, Noctuidae) in transgenic soybean (Glycine max (L.) Merrill Fabales, Fabaceae) cultivar IAS5 expressing a modified Cry1Ac endotoxin. Genetics and Molecular Biology, 31(2), 522-531. http://dx.doi.org/10.1590/S1415-47572008000300020

Krinski, D., Favetti, B. M., Leite-Junior, A. F., \& Gomes, I. T. S. (2013). Use of artificial substrates of different colors for oviposition of brown stink bug Euschistus heros Fabricius, 1794 (Hemiptera, Pentatomidae). Revista Brasileira de Entomologia, 57(3), 319-322.

Martins, G. L. M., Vieira, M. R., Barbosa, J. C., Dini, T. A., Manzano, A. M., Alves, B. M. S., \& Silva, R. M. (2012). Distribuição espacial de Calacarus Heveae feres na cultura da seringueira em Marinópolis - São Paulo. Revista Árvore, 36(2), 211-217.

Maruyama, W. I., Fernandes, M. G., Barbosa, J. C., \& Yamamoto, P. T. (2002). Distribuição espacial de Dilobopterus costalimai young (Hemiptera: Cicadellidae) em citros na região de Taquaritinga, SP. Neotropical Entomology, 31(1), 35-40.

Medeiros, L., \& Megier, G. (2009). Ocorrência e desempenho de Euschistus heros (Heteroptera, pentatomidae) em plantas hospedeiras alternativas no Estado do Rio Grande do Sul, Brasil. Neotropical Entomology, 38(4), 459-463. http://dx.doi.org/10.1590/S1519-566X2009000400003

Melo, E. P., Fernandes, M. G., Degrande, P. E., Cessa, R. M. A., Salomão, J. L., \& Nogueira, R. F. (2006). Distribuição espacial de plantas infestadas por Spodoptera frugiperda (J.E. Smith) (Lepidoptera: Noctuidae) na cultura do milho. Neotropical Entomology, 35(5), 689-697. http://dx.doi.org/10.1590/S1519-566X2006000500018

Morisita, M. (1962). Id-index, a measure of dispersion of individuals. Journal: Researches on Population Ecology, $4(1), 1-7$.

Panizzi, A. R. (1991). Ecologia nutricional de insetos sugadores de sementes. In A. R. Panizzi, \& J. R. P. Parra (1st ed., pp. 253-287). Ecologia nutricional de insetos e suas implicações no manejo de pragas. Manole, São Paulo, SP.

Panizzi, A. R. (1997). Wild hosts of pentatomids: ecological significance and role in their pest status on crops. Annual Reviews Entomology, 42(1), 99-122. http://dx.doi.org/10.1146/annurev.ento.42.1.99

Panizzi, A. R., \& Oliveira, E. D. M. (1998). Performance and seasonal abundance of the neotropical brown stink bug, Euschistus heros nymphs and adults on a novel food plant (pigeonpea) and soybean. Entomologia Experimentalis et Applicata, 88(3), 169-175., 1998. http://dx.doi.org/10.1046/j.1570-7458.1998.00359.x

Panizzi, A. R., \& Slansky, F. (1985). Review of phytophagous pentatomids associated with soybean in the Americas. The Florida Entomologist, 68(1), 184-214. http://dx.doi.org/10.2307/3494344

Panizzi, A. R., Bueno, A. F., \& Silva, F.A. C. (2012). Insetos que atacam vagens e grãos. In: Hoffman-Campo, C.B., Corrêa-Ferreira, B.S., Moscardi, F. Soja: Manejo Integrado de Insetos e outros Artrópodes-Praga. (1st ed., p. 420). Brasília, DF: Embrapa. 
Panizzi, A. R., Galileo, M. H. M., Gastal, H. A. O., Toledo, J. F. F., \& Wild, C. H. (1980). Dispersal of Nezara viridula and Piezodorus guildinii nymphs in soybeans. Environmental Entomology, 9(3), 293-297.

Pereira, M. F. A., Boiça Jr. A. L., \& Barbosa, J. C. (2004). Spatial distribution of Bemisia tabaci (Genn.) biotype B (Hemiptera: Aleyrodidae) on bean crop (Phaseolus vulgaris L.). Neotropical Entomology, 33(4), $499-504$. http://dx.doi.org/10.1590/S1519-566X2004000400016

Pereira, R. G., Albuquerque, A. W., Souza, R. O., Silva, A. D., Santos, J. P. A., Barros, E. S., \& Medeiros, P. V. Q. (2011). Sistemas de manejo do solo: soja [Glycine max (L.)] consorciada com Brachiaria decumbens (STAPF). Pesquisa Agropecuária Tropical, 41(1), 44-51. http://dx.doi.org/10.5216/pat.v41i1.6981

Pielou, E. C. (1977). Mathematical ecology (2nd ed., p. 385). New York: John Wiley \& Sons.

Poole, R. W. (1974). An introduction to quantitative ecology. (1st ed., p. 525). New York: McGraw Hill.

Rabinovich, J. E. (1980). Introducion a la ecologia de problaciones animales. (1st ed., p. 313), México, CECSA.

Ricklefs, R. E. (2003). A economia da natureza. (5th ed., p.470). Rio de Janeiro, Guanabara/Koogan.

Rodrigues, T. R., Fernandes, M. G., \& Santos, H. R. (2010). Distribuição espacial de Aphis gossypii (Glover) (Hemiptera, Aphididae) e Bemisia tabaci (Gennadius) biótipo B (Hemiptera, Aleyrodidae) em algodoeiro Bt e não-Bt. Revista Brasileira de Entomologia, $136-143$. http://dx.doi.org/10.1590/S0085-56262010000100019

Slansky, Jr. F., \& Panizzi, A. R. (1987). Nutritional ecology of seed-sucking insects. In Jr. F. Slansky \& J. G. Rodriguez (Eds.), Nutritional ecology of insects, mites, spiders and related invertebrates (1st ed., p. 1034) . New York, John Wiley \& Sons.

Smaniotto, L. F., \& Panizzi, A. R. (2013). Nymph and Adult Biology on Cultivated and on Non-Cultivated Plants and Seasonal Phenology on Wild Plants of the Neotropical Stink Bug, Euschistus paranticus Grazia (Hemiptera: Pentatomidae). International Journal of Biology, 5(2), 103-110. http://dx.doi.org/10.5539/ijb.v5n2p103

Sosa-Gómez, D. R., \& Silva, J. J. (2010). Neotropical brown stink bug (Euschistus heros) resistance to methamidophos in Paraná, Brazil. Pesquisa Agropecuária Brasileira, 45(7), $767-769$. http://dx.doi.org/10.1590/S0100-204X2010000700019

Southwood, T. R. E. (1978). Ecological methods (2nd ed., p. 525), New York: John Wiley \& Sons.

Souza, L. A., Barbosa, J. C., Grigolli, J. F. J., Fraga, D. F., Maldonado Jr.,W., \& Busoli, A. C. (2011). Distribuição espacial de Piezodorus guildinii na cultura da soja. Anais: XXXII Reunião de Pesquisa de Soja da Região Central do Brasil - São Pedro, SP.

Souza, L. A., Barbosa, J. C., Grigolli, J. F. J., Fraga, D. F., Maldonado, W., \& Busoli, A. C. (2013). Spatial Distribution of Euschistus heros (F.) (Hemiptera: Pentatomidae) in Soybean. Neotropical Entomology, 42(2), 412-418. http://dx.doi.org/10.1007/s13744-013-0136-2

Sturmer, G. R., Cargnelutti, F. A., Stefanelo, L. S., \& Guedes, J. V. C. (2012). Eficiência de métodos de amostragem de lagartas e de percevejos na cultura de soja. Ciência Rural, 42(12), $2105-2111$. http://dx.doi.org/10.1590/S0103-84782012005000145

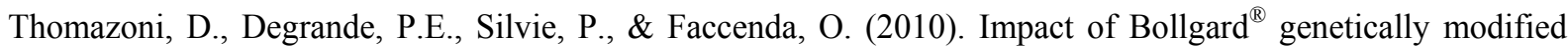
cotton on the biodiversity of arthropods under practical field conditions in Brazil. African Journal of Biotechnology, 9(37), 6167-6176. http://dx.doi.org/10.4314\%2Fajb.v9i37

Vivan, L. M., \& Degrande, P. E. (2011). Pragas da soja. In: Boletim de pesquisa de soja (1st ed., p. 297). Rondonópolis: Fundação MT. (Boletim, 15).

Yokomizo, G. K., Duarte, J. B., Vello, N. A., \& Unfried, J. R. (2013). Análise AMMI da produtividade de grãos em linhagens de soja selecionadas para resistência à ferrugem. Pesquisa Agropecuária Brasileira, 48(10), 1376-1384. http://dx.doi.org/10.1590/S0100-204X2013001000009

Young, L. J., \& Young, J. H. (1998). Statistical ecology: a population perspective (1st ed., p. 565) Boston: Kluwer Academic Publishers.

Yu, H. L., Yun, H. L., \& Kong, M. W. (2011). Risk assessment and ecological effects of transgenic Bacillus thuringiensis crops on non-target organisms. Journal of Integrative Plant Biology, 53(7), 520-538. http://dx.doi.org/10.1111/j.1744-7909.2011.01047.x 
Yuan, L., \& Knauf, V. C. (1997). Modification of plants components. Current Opinion in Biotechnology, 8(2), 227-233.

Zambiazzi, E. V., De Nadai, J., Guilherme, S. R., \& Bonaldo, S. M. (2012). Controle biológico in-vitro do percevejo-marrom (Euschistus heros) com Beauveria bassiana. Revista Trópica - Ciencias Agrárias e Biológicas, 6(2), 44-48.

\section{Copyrights}

Copyright for this article is retained by the author(s), with first publication rights granted to the journal.

This is an open-access article distributed under the terms and conditions of the Creative Commons Attribution license (http://creativecommons.org/licenses/by/3.0/). 